\title{
Internet video - teknik og pædagogik mødes på nettet
}

\author{
Jens Dørup \\ Lektor, Dr. Med. \\ Sektionen for Sundhedsinformatik \& \\ E-læringsenheden \\ Aarhus Universitet \\ jd@hi.au.dk \\ http://www.hi.au.dk/jd
}

\author{
Dorte Sidelmann \\ Cand. Mag. i multimedier \\ E-læringsenheden \\ Aarhus Universitet \\ dorte@iktlab.au.dk \\ http://www.iktlab.au.dk
}
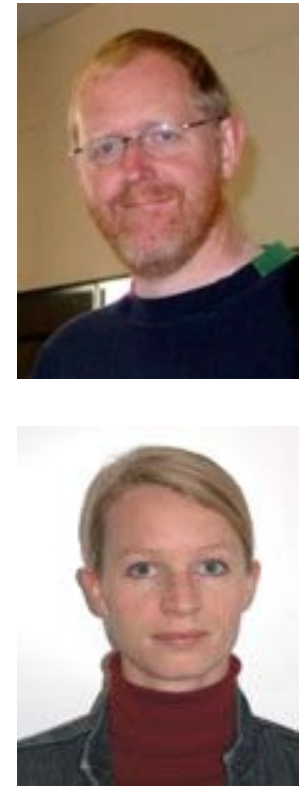

Jens Dørup er leder af Aarhus Universitets e-lcringsenhed (se http://www.iktlab.au.dk og http://www.e-learning.au.dk ) samt leder af Sektionen for Sundhedsinformatik; medlem af det lagevidenskabelige studienæevn ved Aarhus Universitet; næestformand for Dansk Selskab for Medicinsk Uddannelse (http://www.dsmu.dk ); bestyrelsesmedlem i Society for the Internet in Medicine (http://www.internet-in-medicine.org ); bestyrelsesmedlem i EUNIS (European University Information Systems, http://www.eunis.org)

Dorte Sidelmann er IKT-pæedagogisk koordinator ved E-læringsenheden på Aarhus Universitet og beskceftiger sig med inddragelsen af IKT i campusbaseret undervisning såvel som i fjernundervisning. Hun vejleder blandt andet universitetets ansatte i predagogiske og tekniske spørgsmål ved IKT-støttet undervisning.

\section{Introduktion}

De fleste har vel efterhånden oplevet at høre en radioudsendelse eller et stykke musik via Internettet, eller at se en nyhedsudsendelse, en video trailer eller et foredrag. Teknikkerne har været her i nogle år og er efterhånden forfinede og relativt brugevenlige. På universiteterne er nettets båndbredde stor (typisk 10Mbit/s eller $100 \mathrm{Mbit} / \mathrm{s}$ ), og på forskningsnettet, som forbinder de danske universiteter, udnyttes normalt kun en lille del af den tilgængelige båndbredde (Se Dan Mønsters artikel vedr. detaljer om forskningsnettet). Med den stigende udbredelse af ADSL og kabel TV modems er der efterhånden også mulighed for at se video via nettet i hjemmene. Danmark havde i midten af 2003, i hht. IT og Telestyrelsen 11,1 bredbåndsabonnenter pr. 100 indbyggere. Tallet er det største i Europa og overgås på verdensplan kun af Sydkorea og Canada. (http://www.itst.dk/static/publikationer/reports/INTadgangsveje2003/index.htm). 
I betragtning af denne gode Internet adgang kan det måske undre, at der ikke er endnu mere video tilgængeligt på nettet. Det turde være indlysende at mange ville foretrække at se f. eks.

\section{TV kanal URL}

\begin{tabular}{lll} 
DR - Undervis- & \multicolumn{1}{l}{ http://www.dr.dk/undervisning } \\
ning & & http://www.dr.dk/nyheder/tv/Kontant/tvarkiv \\
DR - Nyheder & $\underline{\text { http://tv2.dk }}$ & (Vælg video) \\
TV2 & $\underline{\text { http://www.dk4.dk }}$ & (se: Arkiv) \\
DK4 &
\end{tabular}

Tabel 1: Adresser på nogle danske TV arkiver og ”On Demand” web video arkiver.

en nyhedsudsendelse eller et undervisningsprogram præcis når det måtte passe ind i den travle hverdag, og derfor er der også grund til at forvente at disse muligheder bliver tilgængelige for de fleste indenfor en årrække. Når dette endnu ikke er sket, er det måske, som med hønen og ægget, fordi der endnu er relativt få udbydere. De udbydere som findes, er typisk de store TV selskaber, hvis udsendelser man jo alligevel kan se på TV ved en kvalitet, som stadig er bedre end den, der kan opnås på nettet. Hvad skal der så til for at få balancen til at vende til fordel for mere video på Internettet? Vi forsøger i det følgende at svare på dette spørgsmål under afsnittene:

1. Mere og bedre indhold

2. Mere standardisering og en mere sikker teknik

3. En kulturændring.

\section{Mere og bedre indhold}

Et bud kunne være at flere må i gang med at producere videomaterialer, som er relevante og vedkommende - ikke blot i et nationalt eller regionalt perspektiv, men også i forhold til de perspektiver, som normalt er centrale for uddannelse og forskning:

- Det fagspecifikke perspektiv, hvor en lille gruppe mennesker (narrowcasting) kan have et stort ønske og behov for at udveksle information på en måde, som kan være fri af tid og/eller geografi

- Det internationale perspektiv. Verden er mere og mere én verden og international forsknings- og uddannelsessamarbejde får større og større betydning.

- Det tvær-universitære perspektiv. Paradoksalt nok kan konkurrerende universiteter have stor gensidig gavn af at samarbejde omkring udviklingen af ekspertise og applikationer. Dels kan man spare tid og rejseudgifter, men ikke mindst kan man samle en kritisk masse af interesserede og man kan belyse en problemstilling ved hjælp af synsvinkler, hidrørende fra universiteter med forskelligartet pædagogisk tradition.

\section{Mere standardisering og en mere sikker teknik}

Markedet for Internet video er i dag præget af tre store spillere, så både ved fremstilling, distribution og afspilning af Internet video er man nødt til at tænke på standarder. Danmark er i forhold til resten af verden mere domineret af Microsoft, men selv på et globalt plan er Microsoft Windows med tilhørende standarder for video den primære aktør. En aktuel analyse fra Gartner Group i USA fandt at der blev solgt 155 millioner pc'er i 2003, og Microsoft Windows var installeret på 96,4 pct. af de solgte maskiner. Linux er installeret på 1,5 pct. og 
Apples Mac OS ligger nu på 2 pct. af de solgte. De tre store spillere på området for netbaseret video er Windows Media, Real media og Quicktime:

1. Windows Media filer, som typisk fremstilles med Windows Media Encoder (men også med en række andre programmer) og afspilles i Windows Media Player. Fremstilling og distribution foregår oftest med brug af Microsoft software.

(http://www.microsoft.com/windowsmedia )

2. Real Media filer fremstilles og distribueres normalt med software fra firmaet Real (http://www.real.com), men er ikke kritisk med den anvendt platform. Afspillere til Real media filer fås til Windows, Mac, og Linux. Til gengæld må man finde sig i at den gratis real-afspiller installerer en lang række funktioner og/eller reklamer på computeren, som mange brugere hellere havde været foruden. Produktion og distribution forgår oftest med software fra firmaet Real. Her er begynderløsningerne billige eller gratis, mens man får lov at betale store penge for de mere avancerede løsninger og hvis der skal sendes til mange samtidige brugere.

3. Quicktime (http://www.apple.com/quicktime/) kan både fremstilles og afspilles fra Windows og Mac platformene. Den gratis encoder, som benyttes ved broadcast til Internettet (webcast) findes kun til Mac. Distributionen forudsætter en Darwin streaming media server, som er mindre brugervenlig end Microsofts tilsvarende software, men som kan installeres på alle tre platforme (Windows, Apple eller Linux server).

Som det ses, er der stadig bindinger mellem videostandarderne på den ene side og styresystemer/hardware på den anden. Real forsøger at vinde markedsandele netop ved at slå på kompatibiliteten på tværs af platforme, mens Microsoft tager kampen op ved at fremstille mere og mere software til Mac, sådan at Windows Media i dag kan afspilles på de fleste nyere Mac computere. I praksis benytter langt de fleste Web video arkiver i dag enten Windows Media eller Real, og i Danmark dominerer Windows Media, formodentlig af den simple grund, at afspilleren findes på computeren som en del af Windows, mens afspillere til Real eller Quicktime skal downloades og installeres. Som bruger af web video oplever man problemerne med den manglende standardisering på en række forskellige måder:

1. Døde links: Enten sker der ikke noget, når man klikker på et videolink eller et vindue med en eller anden fejlmeddelelse viser sig.

2. Måske åbner Windows Media Player, Quicktime player eller Real player - men programmet konstaterer at den aktuelle video ikke kan vises.

3. Man bliver bedt om at downloade en ny afspiller, hvilket i nogle tilfælde, men langt fra altid løser problemet.

4. En video kan evt. afspilles fra én arbejdsstation på nettet, men ikke fra en anden. Udover de nævnte problemer med codecs, kan der også være tale om sikkerhedsindstillinger i netværket - såkaldte firewalls, som blokerer for adgangen til nogle videomaterialer.

Området er præget af megen dynamik, så det, som gælder i dag kan være ændret i morgen. Desuden findes der alle former for fordomme, som kan minde om religiøse opfattelser af en given platforms suverænitet frem for andre. Monopoldannelse og manglende kompatibilitet mellem forskellige systemer er altid problematisk, så man håbe at de kræfter, som arbejder på større åbenhed og større grad af inter-operabilitet vil vinde terræn i den kommende tid.

\section{En kulturændring}

Vil TV og computer konvergere som medier? og vil vi i fremtiden kunne vælge mellem ligeså righoldigt et videomateriale, som vi i dag har til rådighed i tekstform på Internettet? I dag er 
der betydelige kulturelle forskelle på vores brug af de to medier. Man ser TV og video på sit fjernsyn - i sin dagligstue - i den bløde stol eller sofa - sammen med familien - og helst ikke med ansigtet "begravet" i skærmen. Computeren er for mange et redskab, som ofte benyttes på arbejdet, mens TV er til underholdning og adspredelse. En sammensmeltning (konvergens) af TV og computermedierne, som der har været mange optræk til, og som der teknologisk set er banet vej for, vil altså forudsætte væsentlige kulturelle forandringer. I dansk mediehistorie bind 4 (1995-2003), diskuteres tendenserne til mediekonvergens (Klaus Bruhn Jensen 2003), men medieforskerne er forsigtige med alt for skårsikre forudsigelser. Samtidig med tendenser til konvergens er der også modsatrettede tendenser. Flere og flere "dimser", store og små, faste og bærbare vil være tilgængelige, så der kan måske paradoksalt være grund til at forvente en samtidig konvergens og divergens af videomedier. At vi samtidigt skal vænne os til at tage mere selvstændigt ansvar (mere pull - mindre push; Se Jens F. Jensen, 1999 side 59-60) vil være en tendens, som ivrige Internetbrugere kender i forvejen, men som andre må lære at tage til sig når web-videoen pludselig dukker op i hjemmene forklædt som fjernsyn.

\section{Video og pædagogik på universiteterne}

Med det stigende fokus på fleksible læreprocesser og blended learning kombineret med krav om formidling af høj kvalitet, kan det undre at der ikke allerede er langt større fokus på videobaserede materialer som læringsressourcer. I dag foregår hovedparten af den fleksible undervisning på universiteterne i Danmark som netbaseret undervisning og udelukkende som skriftlig asynkron kommunikation, og kun i få tilfælde bliver multimedia-materialer inddraget. Det betyder at den netbaserede formidling er underlagt en række begrænsninger, der giver problemer i forhold til at formidle på en tilsvarende nuanceret måde, som den vi kender fra f2f-sammenhænge. Se Rasmus Blok (2004) for en udførlig karakteristik af f2f kommunikation overfor kommunikationen i computermedierede konferencer. Her tænker vi især på at kommunikationen i en f2f undervisningssituation er båret af flere udtryksformer eller meddelelsesformer: det verbale sprog, kropssproget, intonation, og i nogle tilfælde også skriftsproget (ved brug af tavle, overheads, slides mv.) hvorimod den computermedierede kommunikation typisk udelukkende benytter den skriftlige meddelelsesform. Som Rasmus Blok påpeger, giver denne "ensidige" kommunikationsform ikke kun begrænsninger men også en række fordele, som f.eks. reflekterede bidrag til en diskussion, lagring af kommunikationen, og ensartede forhold for at deltage i en diskussion grundet en "udfladning af den sociale hierarkisering”. De nævnte fordele ved den skriftlige kommunikationsform gør sig gældende i forhold til undervisning tilrettelagt som diskussioner om forskellige emner, men ikke direkte i forbindelse med undervisningsstof, der skal formidles gennem visualiseringer om det så drejer sig om visualiseringer vha. fagter og gestik, tegninger på tavlen eller animationer på computeren.

\section{Video som visualisering}

Det er i denne sammenhæng at videobaseret læringsmateriale eller multimediapræsentationer kan spille en væsentlig rolle i universitetsundervisningen. Som artiklerne i dette nummer viser, er videobaseret materiale med fordel blevet anvendt til at formidle programmeringsprocesser, kirurgiske procedurer ved tandoperationer og komplekse kemiske processer mv. (Se artikler af Jens Bennedsen, Anders Nattestad og Per Møller). Undervisningsstof, der kræver at blive visualiseret dynamisk for at blive formidlet mest pædagogisk og med største læringsmæssige udbytte for øje. Som Per Møller skriver: Video er [...] et interessant medie til formidling, fordi det kan visualisere komplekse problemstillinger. Netbaseret videomateriale skal ikke opfattes som en erstatning for formidleren, men derimod som et supplement til f2f formidlingen, fordi det kan fastholde og gengive processer, som kan være tidskrævende og økonomisk bekostelige at udføre eller som måske er umulige at percipere med det blotte øje. Det er i og for sig ikke nyt i forhold til det analoge videomedie. Den afgørende forskel på analog 
og digital videomateriale består pædagogisk set i at digitalt materiale kan distribueres via Internettet uafhængigt af tid/sted og kan integreres med andet materiale i en hypertekstuel struktur, som fordrer aktiv deltagelse fra modtageren. Disse egenskaber giver muligheder for at tilbyde udfordrende og relevant fleksibelt undervisningsmateriale, og som Diba Terese Markus giver eksempel på i sin artikel, findes der i dag redskaber, der gør det teknisk muligt at producere interaktive netbaserede multimediepræsentationer på en forholdsvis simpel måde. At det ikke kræver de store IT-færdigheder eller udstyr at fremstille netbaseret multimediemateriale viser introduktionen til programmerne Windows Media Encoder og Producer også. Til gengæld kræver det overvejelser af pædagogisk art at fremstille anvendeligt videomateriale til Internettet, fordi formidlingen er underlagt nye vilkår.

\section{Iscenesættelse}

Netbaserede multimediepræsentationer kan for eksempel indeholde elementer af den klassiske forelæsning ved anvendelsen af streaming video-teknologi, og her drejer det sig om at iscenesætte og gentænke videooptagelser af forelæsningen, så den passer til mediet. Bo Fibiger pointerer (Fibiger, B., 2004) at udviklingen af læringsressourcer med video-optagelser f. eks kræver nye overvejelser med hensyn til den dramaturgiske model, som ligger til grund for den klassiske forelæsning. En netbaseret forelæsning bør ifølge Fibiger bestå af en række sekvenser af ca. 5 minutters længde - i stedet for de typiske 45 minutter -, hvor de enkelte sekvenser giver en sammenhængende narrativ struktur men samtidig også kan fungere som selvstændige enheder. Samtidig bør iscenesættelse og kamerabrug også tænkes ind i præsentationen af en forelæsning eller lignende på nettet, hvilket Poul Grønkjær i nærværende artikelsamling giver en indføring i på baggrund af mange erfaringer med streaming af forelæsninger på AUC. Her pointerer Grønkjær at brugeren af det netbaserede videomateriale vil opleve sin rolle som henholdsvis beskuer/observatør eller deltager/modtager afhængig af hvordan formidlingen iscenesættes og kameraet placeres. For at afgøre hvilken form for iscenesættelse som er mest hensigtsmæssig, kan det være en hjælp at tage udgangspunkt i en skelnen mellem de tre læringsrum: undervisningsrummet, træningsrummet og studierummet, som Erik Prinds har defineret (Prinds, E., 1999), og de dertil knyttede roller, sproghandlinger og kameravinkler (Fibiger, B., 2004).

\begin{tabular}{|l|l|l|}
\hline Læringrum & Sproghandling & Kameravinkel \\
\hline Undervisning & Tiltale & Frøperspektiv \\
\hline Træning & Omtale & Fugleperspektiv \\
\hline Studie & Samtale & Normalperspektiv \\
\hline
\end{tabular}

Tabel 2: Relationerne mellem læringsrum, sproghandling og kameravinkel ifølge Bo Fibiger (Fibiger, B., 2004).

Denne skelnen er også relevant i forhold til videokonferencer, der på universiteterne anvendes til så forskellige formål som distribuerede forelæsninger, eksaminationer, ph.d. forsvar, seminarer og administrative møder mv., som beskrevet i Dan Mønsters artikel. Der kan dermed næppe være én korrekt iscenesættelse af videokonferencen, men flere forskellige, der tager højde for den aktuelle situation/kommunikation. Mens netbaseret videomateriale typisk er stærkt afhængig af at billedkvaliteten er optimal for at formidle sit budskab, er det bærende element i en videokonference lyden og - som Mønster påpeger - ...Billedsidens vigtigste egenskab er måske i virkeligheden at give en større fornemmelse af nærvcr...Det drejer sig ved videokonferencen således ikke kun om at iscenesætte læringsrummet, men også om iscenesætte nærvœret og dermed give de bedste betingelser for samvœret. 


\section{Videoanvendelser på de danske universiteter}

Vi kan ud fra bidragene til dette tema skelne mellem 2 overordnede anvendelser af netbaseret video på de danske universiteter:

o Videokonference

o Video som undervisningsmateriale:

- (Streaming) Video som enkeltstående materiale

- (Streaming) Video integreret med andet materiale

Begge anvendelser af video som læringsressource har deres styrke i brugen af optiske og auditive udtryksformer, men adskiller sig i de rammer de sætter for interaktion. Videokonference giver i modsætning til "on demand" videobaseret undervisningsmateriale mulighed for at den studerende kan påvirke "undervisningen” gennem dialog, og må siges at være det mest optimale medie af de to, hvis en dialogorienteret (socialkonstruktivistisk) tilgang til læring skal tilgodeses i det virtuelle læringsmiljø.

Videobaseret materiale kan til gengæld fastholde og reproducere processer og situationer vha. lyd, billeder, grafik og tekst i enheder, der kan afspilles når det passer brugeren og så ofte det er nødvendigt. Her kan materialet variere fra det fritstående videoklip til den "iscenesatte” præsentation, hvor videomaterialet sættes ind i en ramme/kontekst og eventuelt integreres med andet læringsmateriale (f.eks en Windows Media Screen Capture vs. en Producer præsentation). I den ene ende af skalaen kan der være tale om rent instruktivistisk videomateriale, der viser hvordan et program, et redskab eller en procedure skal håndteres, og i den anden ende kan man forestille sig undervisningsmateriale, der kombinerer mange "læringsobjekter" med en høj grad af aktivitet fra modtageren side. Sidstnævnte kan potentielt danne grundlag for en konstruktivistisk tilgang til undervisning og alt efter tilrettelæggelse imødekomme flere forskellige læringsstile. Indtil videre har vi primært set det instruktivistiske undervisningsmateriale og de fritstående streaming video-optagelser af forelæsninger produceret i universitets regi, men med de voksende muligheder for at fremstille interaktive multimediapræsentationer uden større tekniske forudsætninger vil vi måske også se mere komplekse digitale undervisningsmaterialer i fremtiden.

\section{Referencer}

Blok, Rasmus. "E-læring - teknologiens muligheder og perspektiver." Tidsskrift for universiteternes efter- og videreuddannelse 2 (2004).

Fibiger, B. "Streaming Video : Tv Eller Computermedieret Kommunikation." i Det digitale nærvær. viden og design i nye medierEd. Simon B. Heilesen. 1. udgave ed.: Roskilde Universitetsforlag, 2004. 
Jensen, Jens F. Internet, World Wide Web, Netværks-Kommunikation. Om Netmedier, Netkulturer, Beboede 3D Virtuelle Verdener Og Meget Mere. Aalborg: Aalborg Universitetsforlag, 1999.

Klaus Bruhn Jensen (red.). Dansk Mediehistorie 4 (1995-2003). 1 ed. Samfundslitteratur, 2003.

Prinds, Erik. Rum Til Læring. En Idé- Og Debatbog Om Nye Læringsformer Med IKT. Kbh: Center for Teknologistøttet uddannelse, 1999. 